\title{
Addressing pregnancy prevention needs of adolescents in East and Southern Africa through education and health sector partnerships
}

\author{
Harriet Birungi \\ Population Council \\ Chi-Chi Undie \\ Population Council \\ Esther Lwanga Walgwe \\ Population Council \\ Francis Obare \\ Population Council
}

Caroline W. Kabiru

See next page for additional authors

Follow this and additional works at: https://knowledgecommons.popcouncil.org/departments_sbsr-rh

Part of the Gender and Sexuality Commons, International Public Health Commons, Maternal and Child Health Commons, and the Women's Health Commons

How does access to this work benefit you? Let us know!

\section{Recommended Citation}

Birungi, Harriet, Chi-Chi Undie, Esther Lwanga Walgwe, Francis Obare, Caroline W. Kabiru, and Joyce Mumah. 2017. "Addressing pregnancy prevention needs of adolescents in East and Southern Africa through education and health sector partnerships," presentation at 2017 Family Planning Summit, London. 


\section{Authors}

Harriet Birungi, Chi-Chi Undie, Esther Lwanga Walgwe, Francis Obare, Caroline W. Kabiru, and Joyce Mumah 


\section{Addressing Pregnancy Prevention Needs of Adolescents in East and Southern Africa through Education and Health Sector Partnerships}

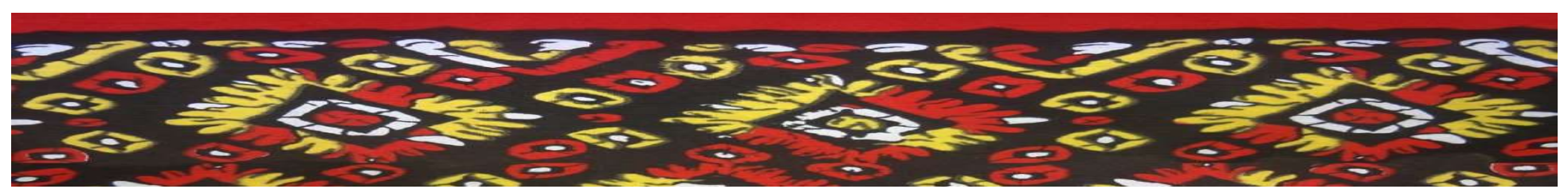

Harriet Birungi, Chi-Chi Undie, Esther Lwanga, Francis Obare Population Council

Caroline Kabiru, Joyce Mumah

African Population and Health Research Center 


\section{What's so special about the education sector?}

- It's where the adolescents are (or should be!)

- Policies of Universal Primary Education in the region

- It's where we begin to lose many adolescent girls

- It's a place of opportunities

- Links between education and health

- Upholding of rights ('Education For All')

- Sustained behaviors, interventions, etc.

- It's important for SDG 4 \& 5 
Education sector response to UP the current picture

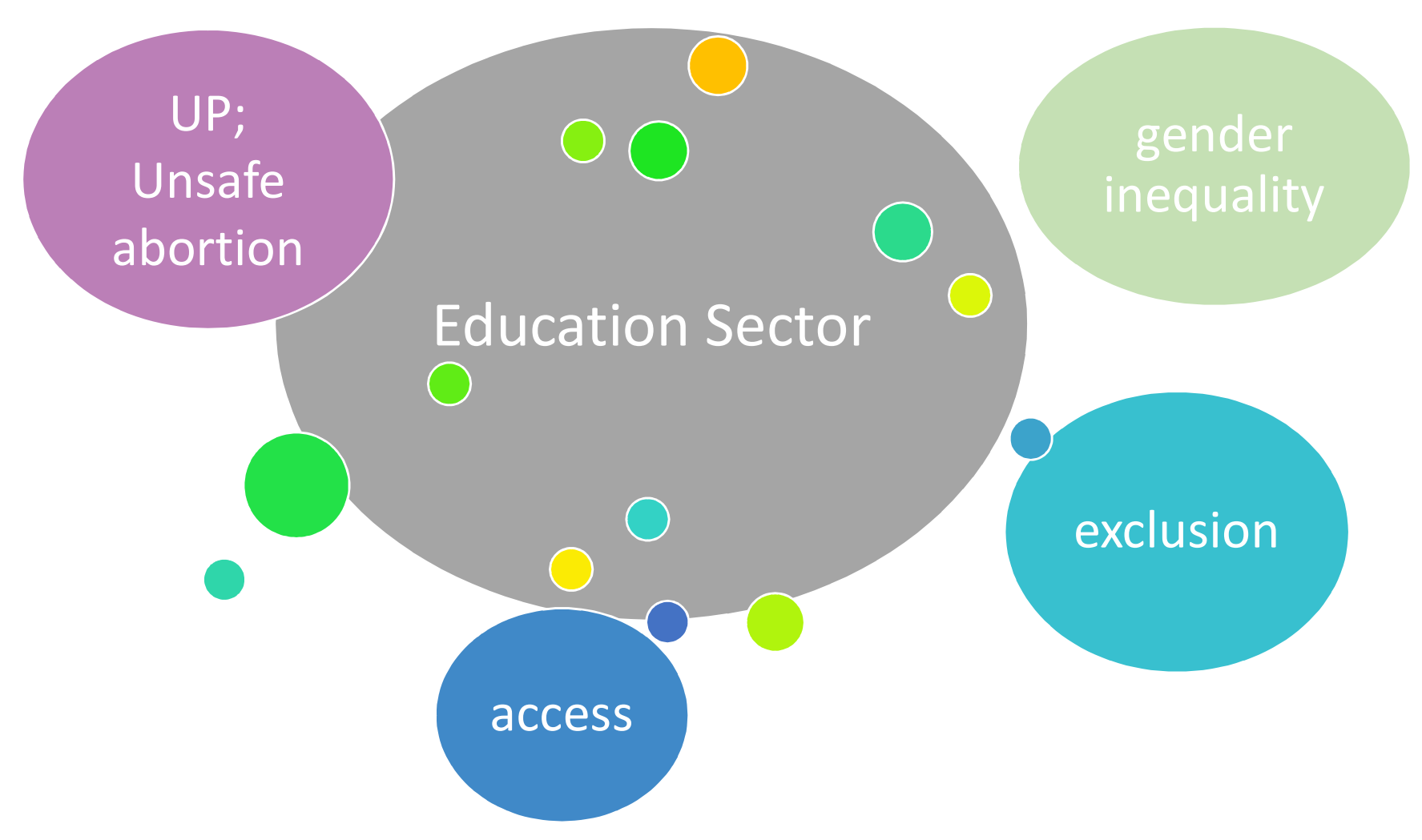




\section{We are seeing a regional crisis in ESA--}

High unintended pregnancy rates (40-60\%) among girls $15-19$ years

\begin{tabular}{|l|c|}
\hline Country & $\begin{array}{c}\text { Unintended Pregnancy } \\
(\%)\end{array}$ \\
\hline Kenya & 59 \\
\hline Malawi & 44 \\
\hline Tanzania & 39 \\
\hline Uganda & 47 \\
\hline Zambia & 58 \\
\hline Source: Demographic and Health Survey; & \\
\hline
\end{tabular}

A LARGE PROPORTION OF CLIENTS SEEKING POST-ABORTION SERVICES AT HEALTH FACILITIES ARE BELOW 20 YEARS Y

$17 \%$ (Kenya),

21\% (Malawi),

49\%-58\% (Tanzania),

$60 \%$ (Zambia),

68\% (Uganda)

(Source Guttmacher Institute 2009; Levandowski et al. 2009; Mirembe 1996; Rasch and Kipingili 2009; Republic of Kenya 2013).

\section{KENYA: 47\% STUDENTS EXPERIENCE} SEVERE UNSAFE ABORTION COMPLICATIONS (Source: MOH. 2013 Incidence and complications of Unsafe abortion in
Kenya) 
How is the education sector responding? 


\section{Life Skills Education (LSE) is inadequate}

A six country review (Botswana, Kenya, Malawi, Uganda, Tanzania, Zambia) shows that LSE:

- Lacks basic aspects of sexual health and gender issues

- Pregnancy prevention (including condoms \& contraceptives) not a central feature of the content

- Condoms taught in Botswana, Malawi \& Uganda

- LSE content on contraceptives

- Included in Zambia (new), No information on contraceptives (Kenya, Malawi).

- Unclear whether LSE includes contraceptives (Botswana, Tanzania)

- Included in Uganda (only in Islamic Religious curriculum)

-When offered at all, pregnancy prevention happens when its too late - at secondary school level alone

- Pregnancy prevention information poorly or not delivered at all in most schools 


\section{A six country review of policies and practices ......}

- None of the countries utilizes a continuation policy for school re-entry for pregnant girls

- Countries have re-entry policies, but with varying degrees of implementation and adherence

- Mandatory pregnancy screening happens in all countries, without clear links to schooling continuation or pregnancy prevention

- None of the countries keeps track of girls who drop out of school

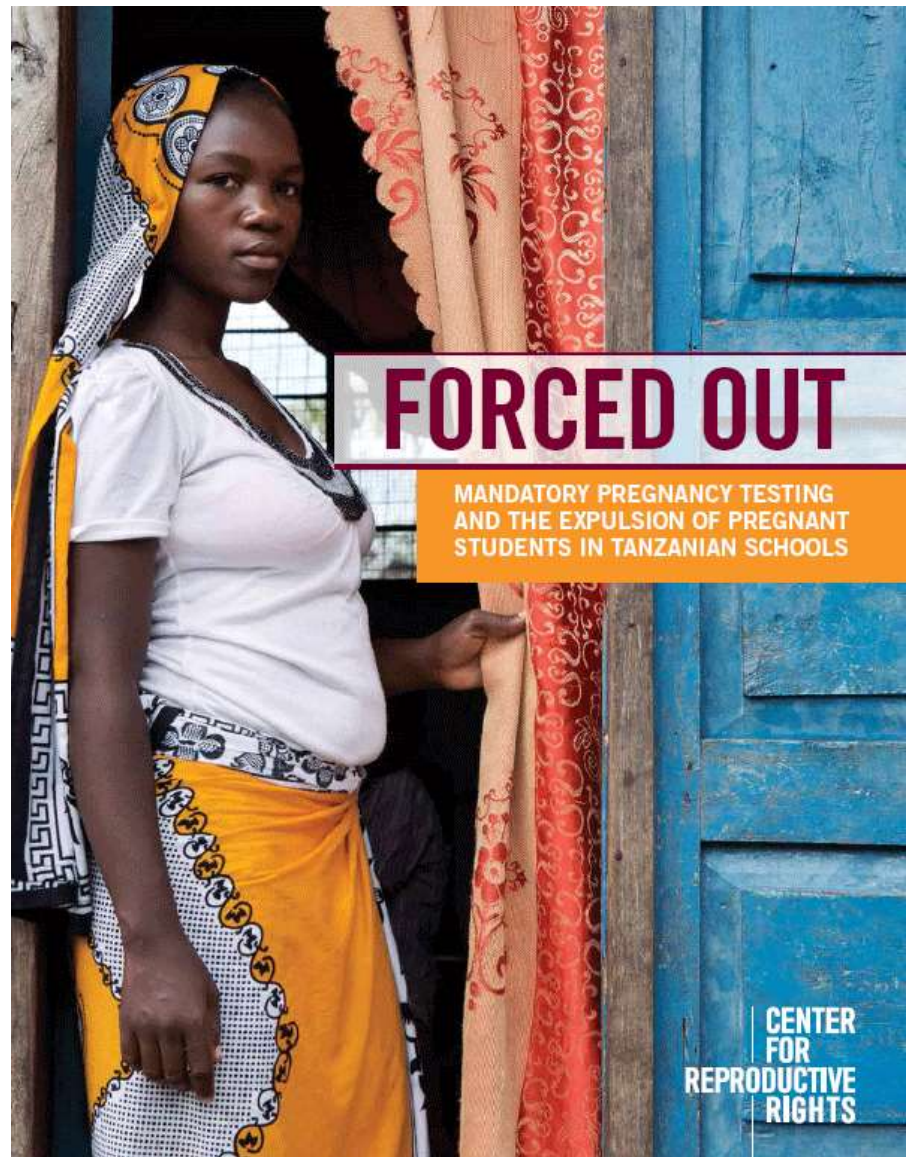




\section{No surprise, then, that.....}

\begin{tabular}{|l|c|c|}
\hline Country & $\begin{array}{c}\text { Ever pregnant (\%) } \\
\text { 15-19 YEARS }\end{array}$ & $\begin{array}{c}\text { \% out of school among ever } \\
\text { pregnant }\end{array}$ \\
\hline Kenya & 18 & 98 \\
\hline Malawi & 26 & 97 \\
\hline Tanzania & 23 & 99 \\
\hline Uganda & 24 & 98 \\
\hline Zambia & 28 & 95
\end{tabular}

Source: Demographic and Health Survey;

EARLY PREGNANCY MEANS END OF SCHOOLING 


\section{Early and unintended pregnancy main reason for dropping out of school}

Out-of-school teen girls in Homa Bay, Kenya $(n=728)$

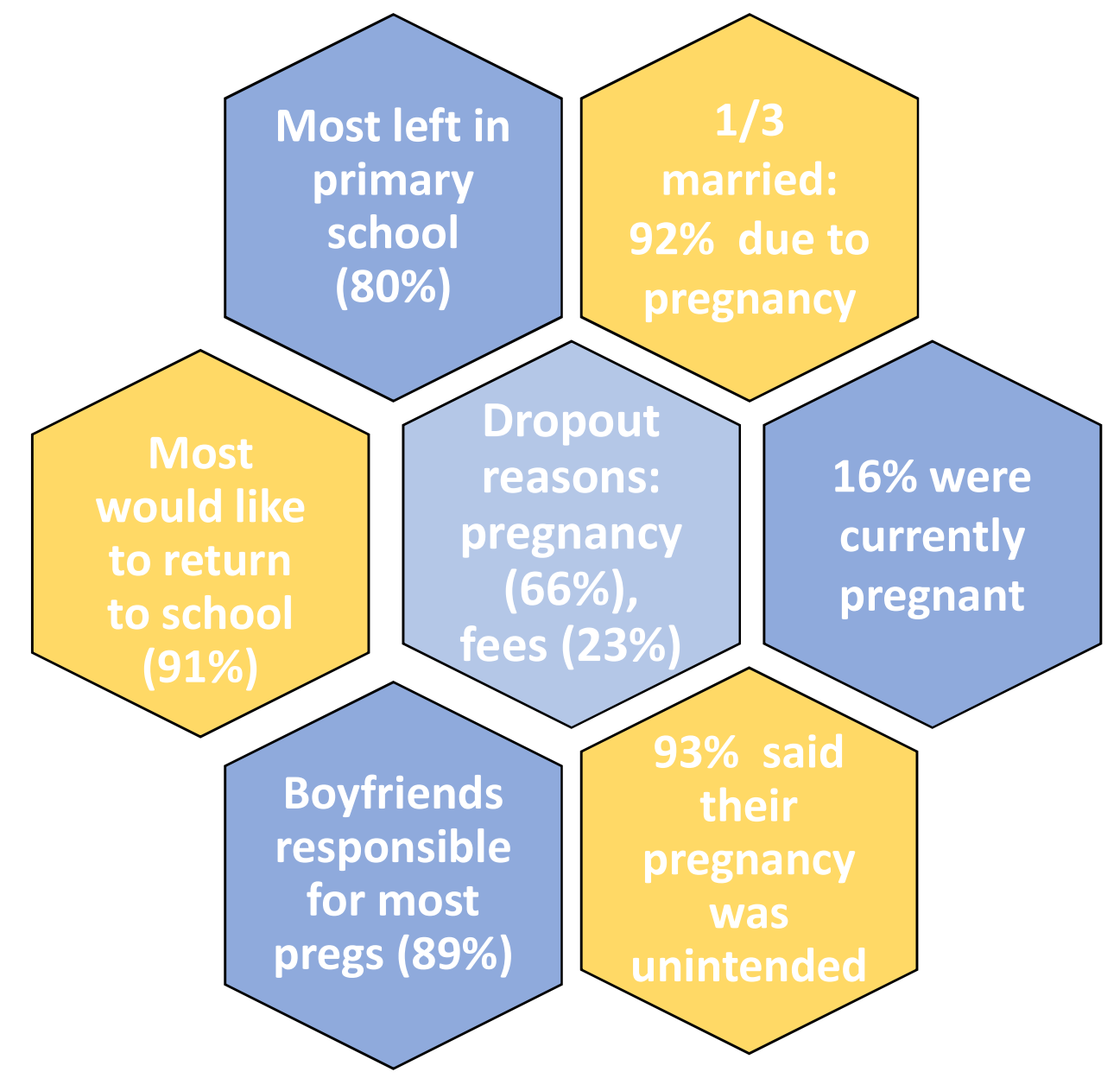




\section{Building strong partnership}

Closely articulating

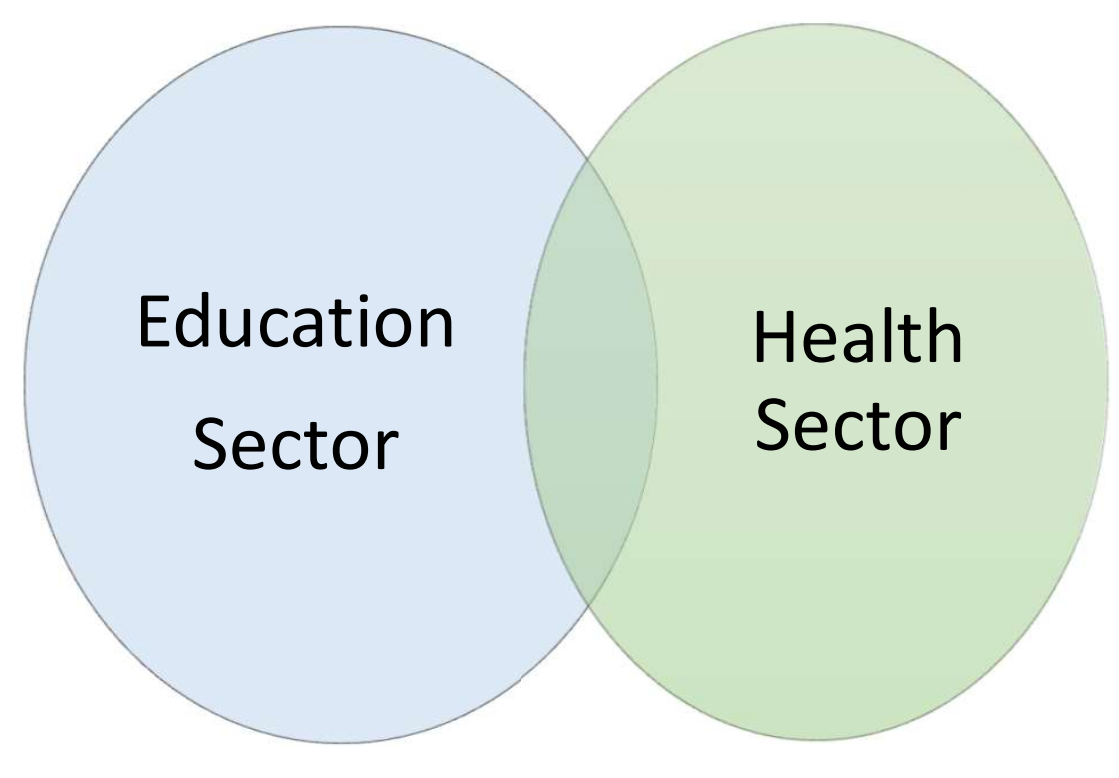

- Shared policies

- Adolescent Sexual and Reproductive Health

- School Health Policy

- Share human resources

- Shared outcomes wellbeing

But

- Different approaches 


\section{Health and Education Sector Stakeholder Dialogues}

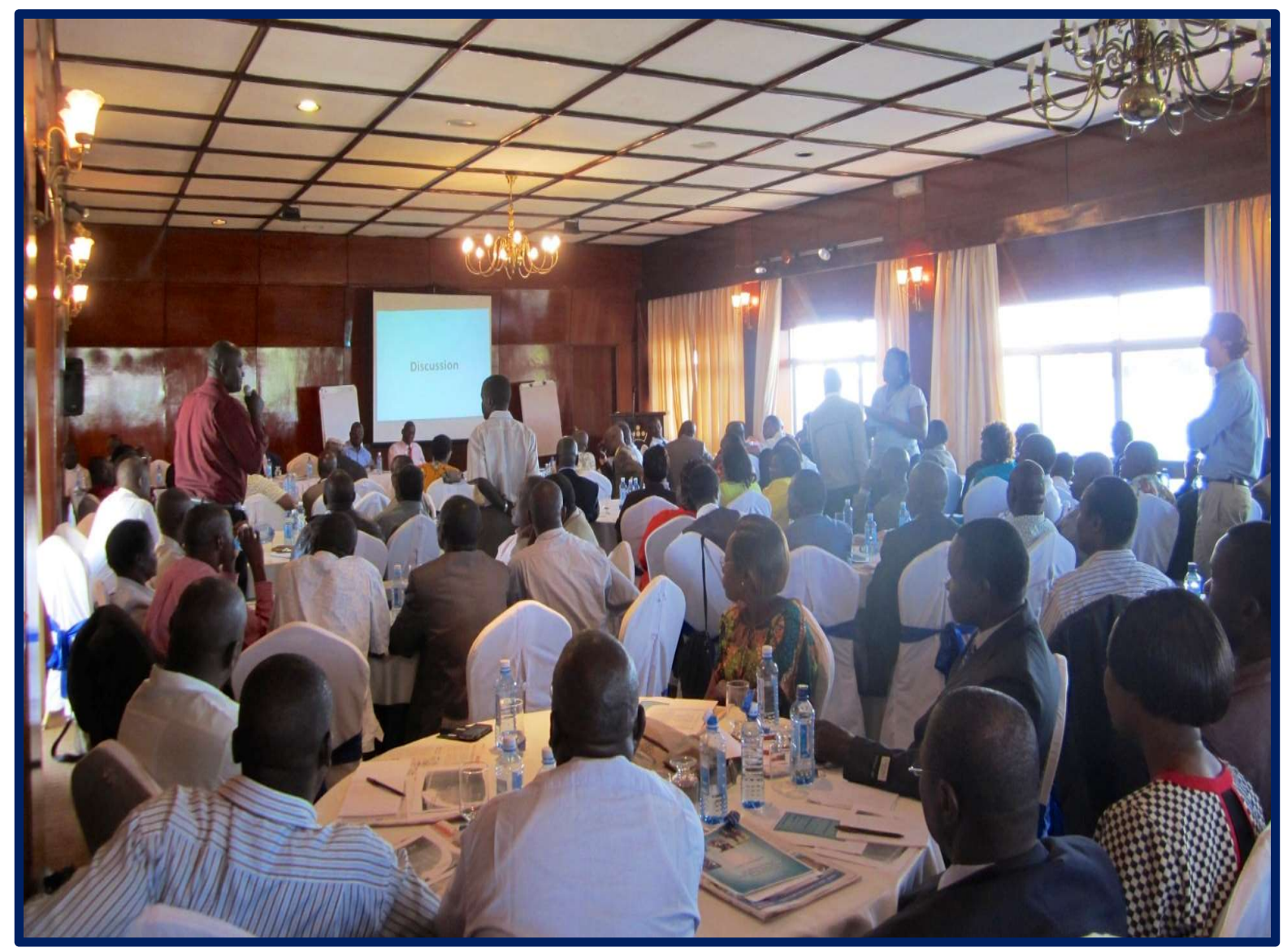

Foster awareness of School health School policy and shared responsibilities

We need to spell it out ....

CSE delivered by teachers is ineffective \& costly

- Education sector needs the health sector to deliver on pregnancy prevention in schools including access to services

- Health sector needs education sector to reach out to new users and sustain the behavior

Talking about rights - mandatory pregnancy screening without preventive information is unacceptable 


\section{Re-thinking our approaches....}

Compelling evidence that 'speaks to' endusers

1) How many girls are out school because of pregnancy?

2) Documentation of repeat pregnancies in schools

3) Can school nurses deliver pregnancy prevention information and services in schools

4) Evidence-based model for school health linkages

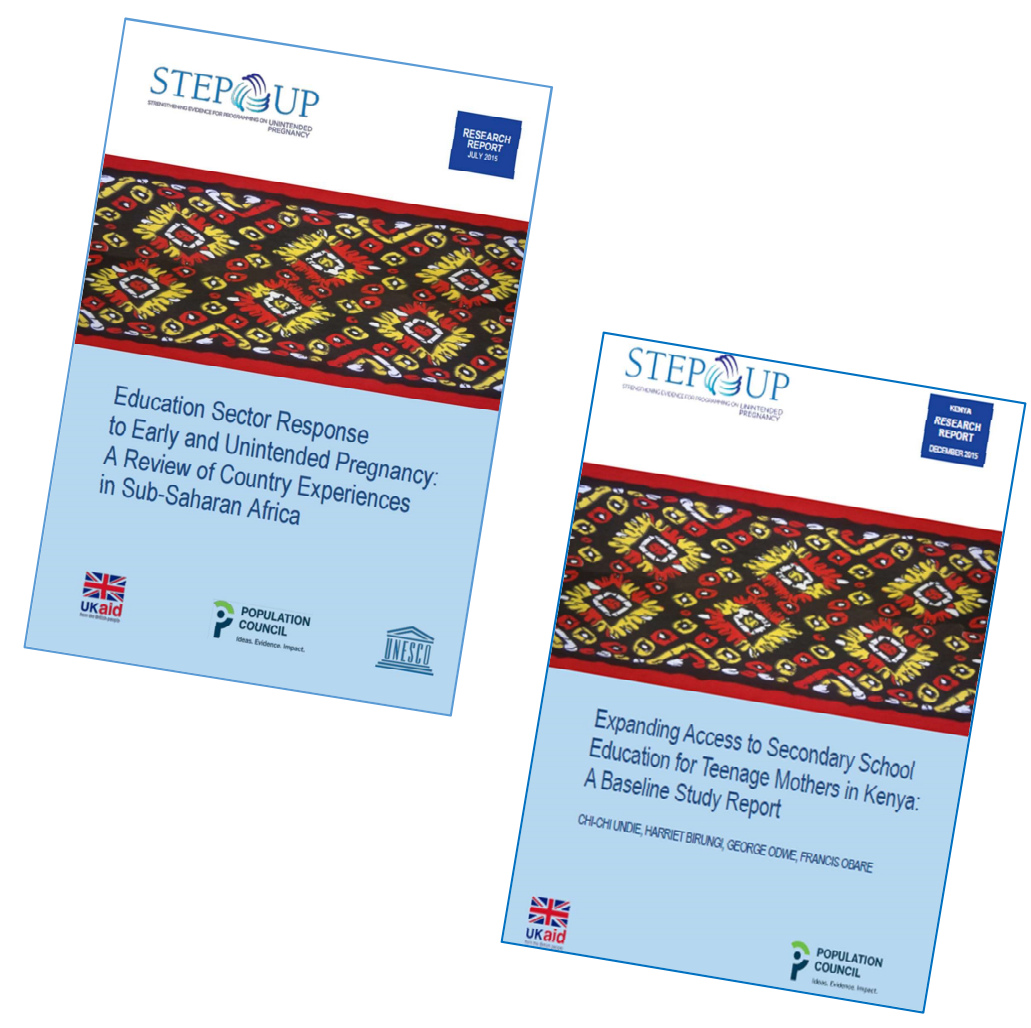




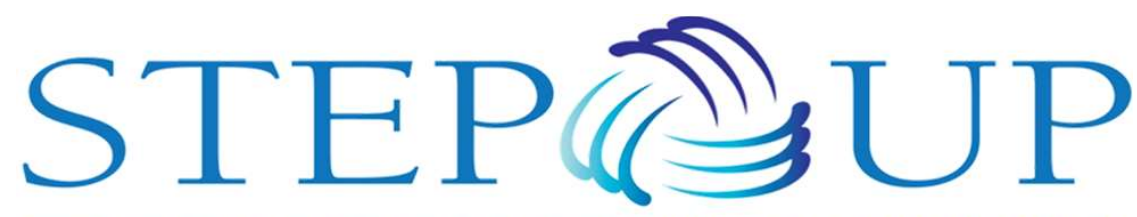

STRENGTHENING EVIDENCE FOR PROGRAMMING ON UNINTENDED

The STEP UP (Strengthening Evidence for Programming on Unintended Pregnancy) Research Programme Consortium is coordinated by the Population Council in partnership with the African Population and Health Research Center; icddr,b; the London School of Hygiene and Tropical Medicine; Marie Stopes International; and Partners in Population on Development. STEP UP is funded by UK aid from the UK Government.

\section{POPULATION} COUNCIL

Ideas. Evidence. Impact.

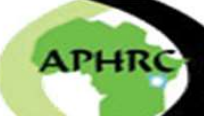

African Population and Health Research Center
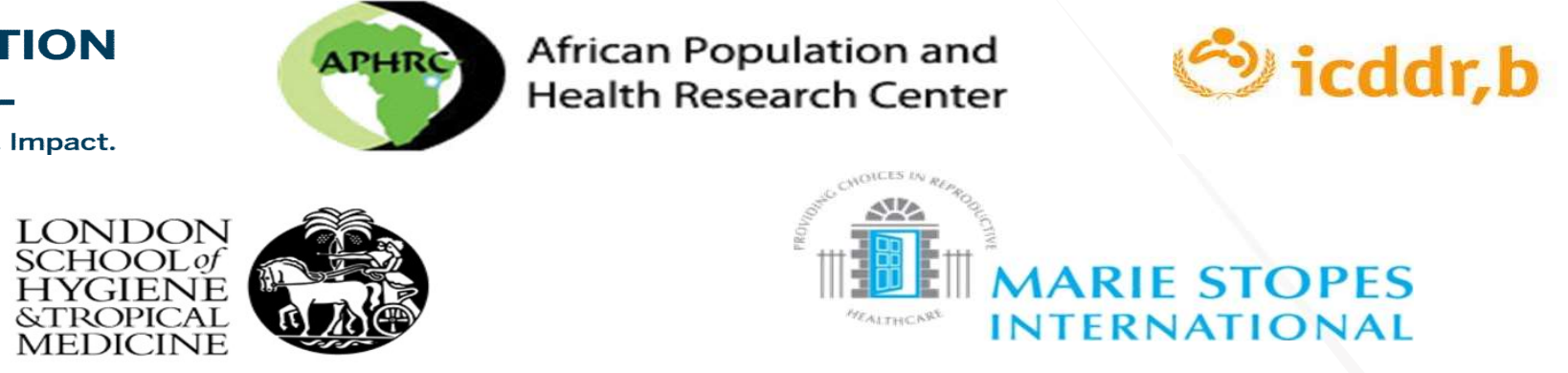